\title{
Storage of corn seeds infested by weevil
}

\author{
Leidiane de Oliveira Costa' (D) https://orcid.org/0000-0001-5199-9801 \\ Sheury Celante Marques² (D) https://orcid.org/0000-0002-3794-3753 \\ Rosane Rodrigues da Costa Pereira ${ }^{3, *}$ (D) https://orcid.org/0000-0002-3375-4322 \\ Carlos Eduardo Pereira ${ }^{3}$ (D) https://orcid.org/0000-0002-8355-1128 \\ 1. Universidade Federal Rural de Pernambuco- Departamento de Agronomia - Laboratório de Entomologia - Recife (PE), Brazil. \\ 2. Universidade Estadual Paulista “Júlio de Mesquita Filho"- Faculdade de Engenharia de Ilha Solteira - Departamento de \\ Fitotecnia, Tecnologia de Alimentos e Sócio Economia - Ilha Solteira (SP), Brazil. \\ 3. Universidade Federal do Sul da Bahia- Campus Jorge Amado - Centro de Formação em Ciências Agroflorestais - Itabuna (BA), Brazil. \\ *Corresponding author: rosaneilheus@gmail.com
}

\begin{abstract}
Weevil is one of the main pests of stored corn. The adults feed on intact and broken seeds or bran, while the larvae develop by feeding on the inside of the seeds, resulting in a reduction in weight and physiological quality. The objective of this study was to evaluate the effects of Sitophilus zeamais infestation on corn seeds during storage. Corn seeds were infested using insect densities: $0,36,72,108$, and 144 individuals per $240 \mathrm{~g}$ of seeds. The infested seeds were placed in individualized plastic containers and covered with voile fabric. The seeds were stored for 60 days under laboratory conditions with an average temperature of around $27^{\circ} \mathrm{C}$ and relative humidity of $85 \%$. Initially and every 15 days of storage for 60 days, the seeds were evaluated using the parameters: number of S. zeamais individuals, total number of infested seeds, seed weight loss, germination test and seedling emergence in the tray. The population increase of $S$. zeamais causes a decrease on the physical and physiological quality of stored corn seeds, but the deterioration rate does not increase in the same proportion as the weevil population growth rate.
\end{abstract}

Keywords: germination; physical damage; Zea mays; Sitophilus zeamais.

\section{INTRODUCTION}

Corn (Zea mays L.) production has increased in recent decades in different regions of the world and Brazil is the third largest producer in the world (FAO, 2020). Corn contributes substantially to increase grain production in Brazil with 82,288 million tons in the 2018/2019 harvest (CONAB, 2020).

The seeds are basic inputs for the corn crops and their quality is important to obtain high productivity. It is necessary that the seeds do not suffer rapid deterioration during storage to reach the rural producer with high-quality. Seeds can deteriorate rapidly in inadequate storage conditions (STEFANELLO et al., 2015), mainly by insect pests.

The losses by insect pest attack are greater due inadequate sanitary conditions of the warehouse infrastructure and climatic conditions that favor this biota. According to BESKOW; DECKERS (2002) the annual average of quantitative grains losses in Brazil corresponds to $10 \%$ up to total loss in some warehouses.

Corn weevil (Sitophilus zeamais Motschulsky, Coleoptera: Curculionidae) is a severe internal primary pest of stored products. The severity of this pest is due to its high reproductive capacity and short life cycle. On average, this insect oviposits 282 eggs (GALLO et al., 2002) during about 43 days of the biological cycle (MARSARO JÚNIOR et al., 2008), with the total instar larval developmental period being 23.1 days on corn (OJO; OMOLOYE, 2016). The longevity of this species is approximately 140 days (SOUSA et al., 2009).

It is polyphagous and its attack can start in the field and continue during storage, causing weight loss, reduction in germination, nutritional and commercial value of the grains (SILVEIRA et al., 2006; SORI;AYANA, 2012). Also, larvae and adults of $S$. zeamais feed on the endosperm, which results in secondary attack by fungi (VIEBRANTZ et al., 2016). Such losses can reach more than $90 \%$ in terms of weight, in addition to qualitative damages (MUZEMU et al., 2013; NUKENINE et al., 2002).

Received: Nov 4, 2020. Accepted: Oct 31, 2021

Associate Editor: Silvia Galleti

Peer Review History: Double-blind Peer Review. 
Due to the biotic potential of weevil, the speed of seed deterioration is likely to accelerate with the increase of its population. Thus, the objective of this work was to evaluate the effects of $S$. zeamais infestation on corn seeds during storage.

\section{MATERIAL AND METHODS}

\section{Study sites and experimental design}

The tests were conducted in laboratory conditions in the city of Humaitá, state of Amazonas, Brazil. Corn seeds of the cultivar Al 25 were used without chemical treatment. The insects of the species $S$. zeamais used for infestations were obtained from the rearing at the plant health laboratory.

Infestation levels of $0,36,72,108$ and 144 adult insects without sex determination per $240 \mathrm{~g}$ of seeds were used to determine the lesions caused by S. zeamais on corn seeds. The insects were separated and counted $24 \mathrm{~h}$ before the infestation and were maintained without food for that period. The seeds were placed in each container and then infested with the population density corresponding to the treatment. Each container was considered a repeat. The storage containers for the insects were made of plastic with a $0.5-\mathrm{L}$ capacity and were covered with voile fabric, attached with rubber ties to exchange gas and prevent insects from escaping.

The infested seeds were stored in laboratory environment with average temperature of around $27^{\circ} \mathrm{C}$ and relative humidity of $85 \%$.The seeds were evaluated initially and every 15 days of storage for 60 days.

The tests were conducted in a completely randomized design in a $5 \times 5$ factorial scheme (five infestation densities and five evaluation periods), with four replications.

\section{Seed analysis}

The parameters and procedures used to evaluate the action of the curculionid on corn seeds were:

1) Number of seeds infested by insects: seeds containing larvae, pupae and adults were considered attacked, as well as an insect penetration or exit hole;

2) Total number of insects: obtained by counting the total number of adults and larvae of $S$. zeamais present in the seeds;

3) Seed weight loss: obtained by weighing, in grams, the containers on each evaluation date;

4) Germination test: four subsamples of 50 seeds were sownin a paper roll moistened with 2.5 times its weight in water and kept in a germinator at $25^{\circ} \mathrm{C}$. The germination percentage was determined five days after sowing by number of normal seedlings according to the Rules for Seed Analysis (RAS) (BRAZIL, 2009);

5) Seedling emergence test in tray: the samples were collected in the same way as in the germination test, with sowing in plastic trays with substrate sand + soil $(2: 1)$. The trays were kept in a greenhouse with an average temperature of approximately $28^{\circ} \mathrm{C}$, with daily irrigation. Emerged seedlings were evaluated 14 days after sowing.

\section{Statistical analysis}

The data on the number of infested seeds and the total number of insects were transformed to $\sqrt{ }(x+0.5)$ and the germination and seedling emergence percentage to arcsene $\sqrt{ }(x / 100)$. The averages obtained were analyzed using the SISVAR statistical program (FERREIRA, 2011). Data was submitted to F-test $(\mathrm{p} \leq 0.05)$ and means were compared using regression analysis and Scott-Knott test.

\section{RESULTS AND DISCUSSION}

The effects of the infestation level, storage periods and its interaction were significant for all the variables studied in this work (Table 1). 
Table 1. Mean squares of the infested seeds number (ISN), total number of insects (TNI), loss of seed weight (LSW), germination percentage (GP), seedling emergence percentage (SEP) of corn initially infested with Sitophilus zeamais and evaluated during storage.

\begin{tabular}{lcccccc}
\hline \multirow{2}{*}{ SV } & DF & \multicolumn{5}{c}{ Mean Squares } \\
\cline { 3 - 7 } & & ISN & TNI & LSW & GP & SEP \\
\hline Infestation $(\mathrm{I})$ & 4 & $160.608^{* *}$ & $489.745^{* *}$ & $633.49^{* *}$ & $0.135^{* *}$ & $0.166^{* *}$ \\
\hline Time $(\mathrm{T})$ & 4 & $189.076^{* *}$ & $17.456^{* *}$ & $1729.69^{* *}$ & $0.278^{* *}$ & $0.297^{* *}$ \\
\hline $\mathrm{I} \times \mathrm{T}$ & 16 & $14.585^{* *}$ & $2.017^{* *}$ & $116.69^{* *}$ & $0.018^{* *}$ & $0.049^{* *}$ \\
\hline Error & 75 & 0.022 & 0.128 & 0.630 & 0.007 & 0.009 \\
\hline
\end{tabular}

${ }^{* *}$ Significant at $1 \%$ probability; SV: source of variation; DF: degrees of freedom.

The evaluation of the population growth of $S$. zeamais showed that the number of individuals did not increase when there was no artificial infestation of the seeds with these insects, indicating that the seeds were free of the pest at the experiment installation time and there was no subsequent contamination (Fig. 1). There is an increase in the population of S. zeamais over the storage period for the other treatments.

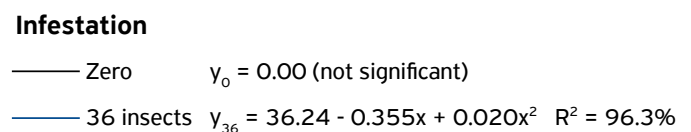

(a)

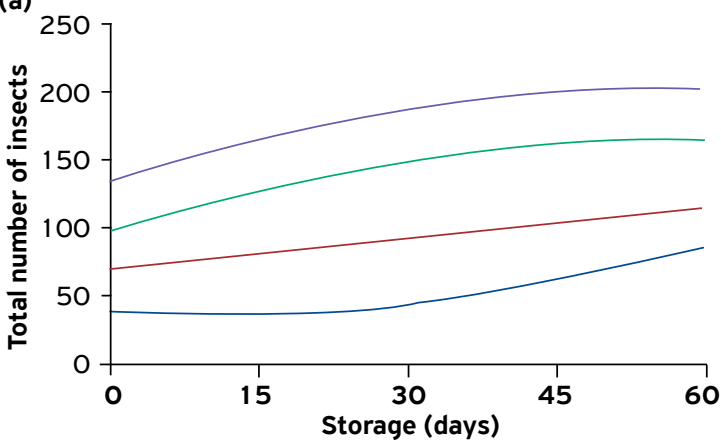

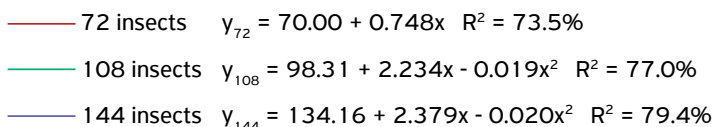

(b)

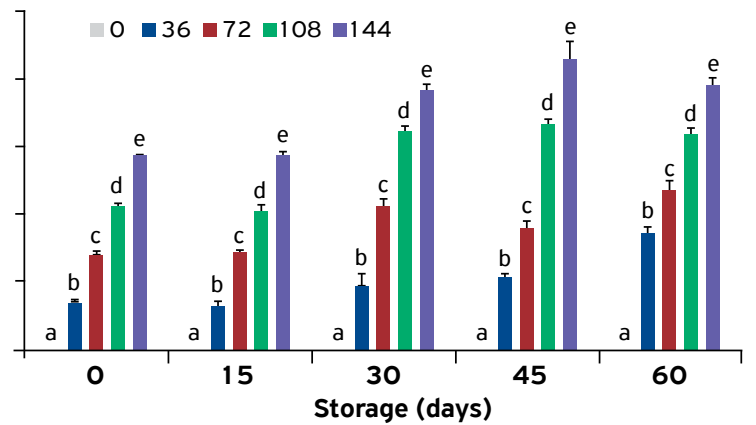

Figure 1. Total number of Sitophilus zeamais individuals in corn seeds with different levels of initial infestation, evaluated during storage using regression analysis (a) and Scott-Knott test (b). Means followed by the same letter in each storage period are not significantly different $(p \leq 0.05)$. Bars at the top of columns indicate the media standard error.

Source: Elaborated by the authors.

The larger the initial population of this pest, the greater the final population observed at 60 days of storage. There is a slow growth in the population up to 30 days when seeds were infested with 36 individuals and starts to increase more quickly after this period. The population growth of $S$. zeamais shows a linear growth trend to the infestation with 72 individuals according to the mathematical model adjustment (Fig. 1a).

There is also a population growth of the infestations with 108 and 144 individuals; however, it shows a second-degree polynomial model adjustment, with a tendency to stabilize growth around 45 days of storage. This change that occurred in the pest population dynamics in treatments with major initial infestations may be due to the occurrence of competition for food. This competition is dependent on population density and regulates the growth.

GUEDES et al. (2010) suggest in their work the presence of severe competition between larvae of S. zeamais induced by food limitation, with cannibalism occurring. DANHO et al. (2002), working with infestation of 50 individuals of S. zeamais in lots with 800 and 200 grains of corn, observed a smaller number of eggs in the smaller lot. In this same work, a maximum emergence of adult weevils was verified when the number of grains was greater, indicating a possible adaptive reproductive strategy.

However, the statistical difference initially observed in the weevil population by artificial infestation was maintained throughout the storage period (Fig. 1b). Similarly, SILVA et al. (2006) found that the population growth of S. zeamais in wheat seeds was affected by the population size that initiated infestation, so the greater the initial infestation, the greater the population growth during storage at $28^{\circ} \mathrm{C}$. 
Also, by the number of seeds infested verified, no seeds with injuries or presence of S. zeamais were observed in the treatment without infestation, indicating that there was no seed attack by this pest before the installation of the experiment (Fig. 2). For the other levels of seed infestation, it was found that the presence of these curculionids at the beginning of storage significantly increases infested seeds number during storage due to the population growth previously discussed.

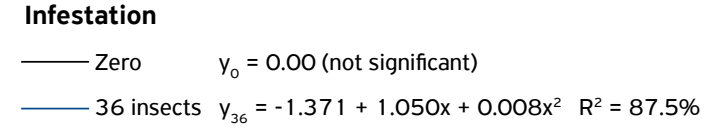

(a)

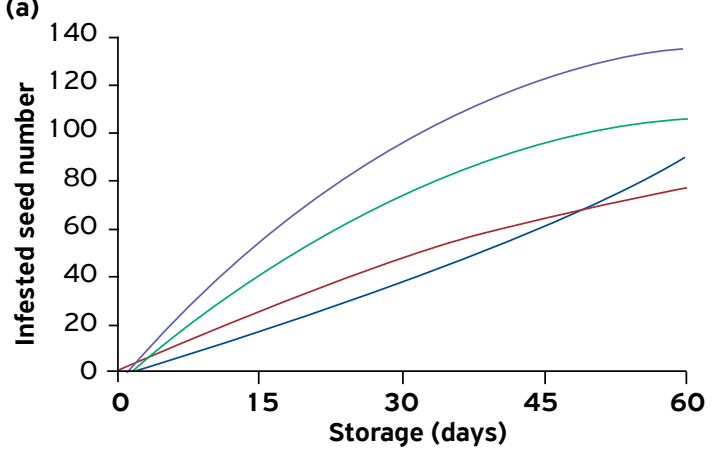

Infestation

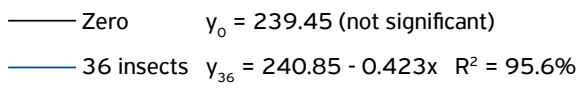

(c)

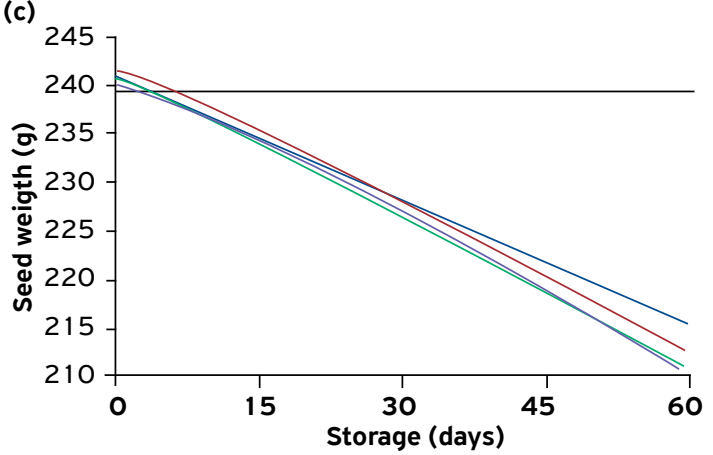

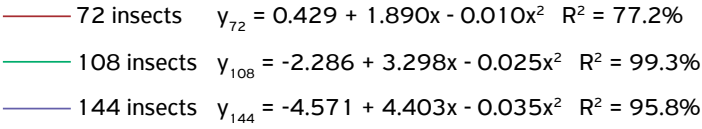

(b)

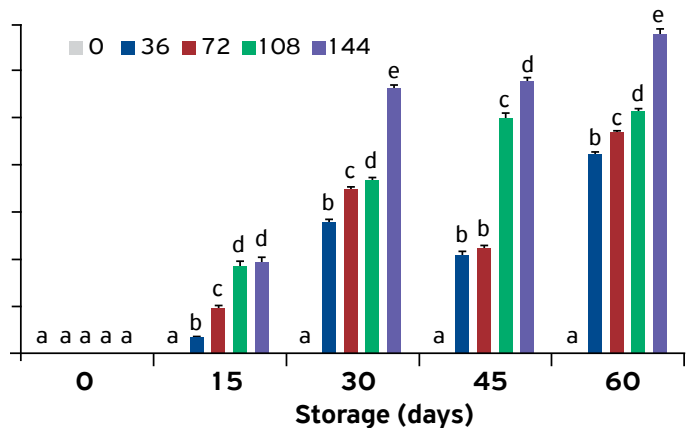

(d)

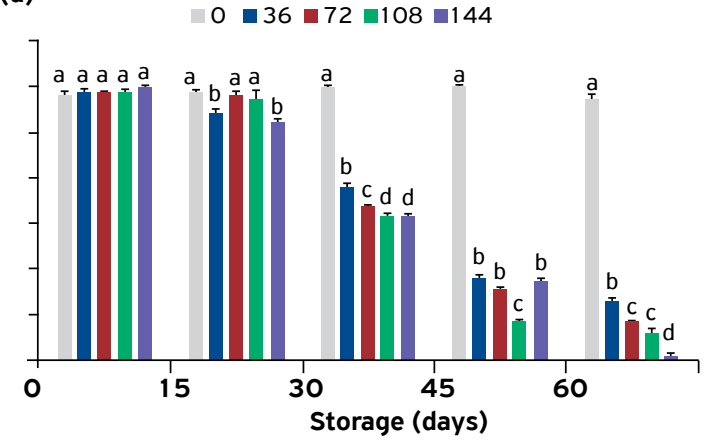

Figure 2. The number of seeds with damage caused by S. zeamais and weight of corn seeds with different levels of initial infestation, evaluated during storage using regression analysis (a, $c$ ) and Scott-Knott test (b, d). Means followed by the same letter in each storage period are not significantly different $(p \leq 0.05)$. Bars at the top of columns indicate the media standard error.

Source: Elaborated by the authors.

The injuries on the seeds were even greater mainly after 60 days of storage for the treatments with 108 and 144 individuals. In all treatments, except for the one in which there was no insect infestation, there was a quadratic model adjustment that explains the variation in the number of infested seeds according to the seed exposure time (Fig. 2a).The magnitude of differences in the number of infested seeds between the infestation levels increases during storage (Fig. 2b).

It was also verified that there was no variation of the seed weight when the seeds were not infested with S. zeamais, while for the other treatments significant losses were observed during storage (Fig. 2c). According to CARVALHO; NAKAGAWA (2012), the pest insects that develop in the seeds during storage can cause a lot of damage, among which weight loss stands out. The occurrence of pest insects during storage also results in reduction of the density of the grains (VIEBRANTZ et al., 2016).

When the initial infestation was with 36 insects, the number of individuals estimated at 60 days was 85.2 and the average weight loss $10.5 \%$. For the initial infestation of 144 insects, the final number of individuals at 60 days was 203.8 and the average weight loss was $12.43 \%$. However, these losses are greater depending on environmental conditions and initial population (ALAM et al., 2019; SORI; AYANA, 2012).

The results show that an initial population of $S$. zeamais more than four times larger does not necessarily correspond to a similar weight loss. This result corroborates with CANEPPELE et al. (2003), who found that the grain weight loss almost 
doubled to infestations with 5 to 15 insects, and with 50 insects the loss was only two and a half times and not ten times as can be suppose.This relationship may be associated with a possible competition between the individuals of $S$. zeamais during larval stage (GUEDES et al., 2010).

At 30 days of storage, all treatments with infestation differed significantly from the control treatment and this difference was accentuated in the next evaluation periods (Fig. 2d).

There were no significant differences in the percentage of germination and seedling emergence during storage of noninfested seeds (Fig. 3).

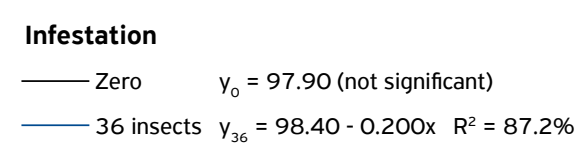

(a)

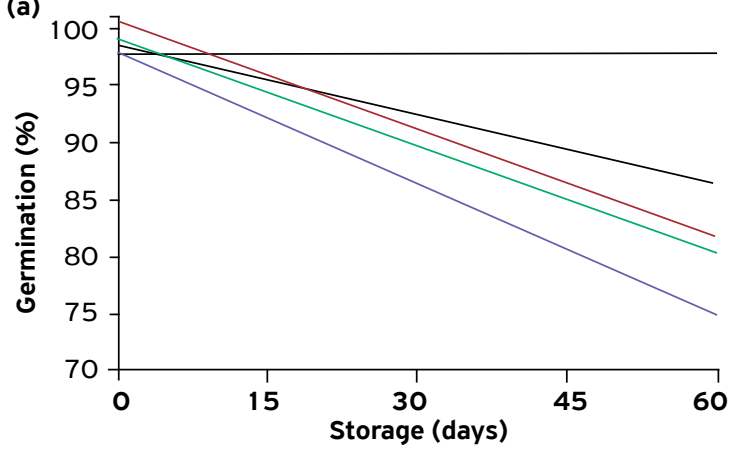

Infestation

Zero $\quad y_{0}=98.00$ (not significant)

36 insects $y_{36}=97.79+0.222 x-0.006 x^{2} \quad R^{2}=94.7 \%$

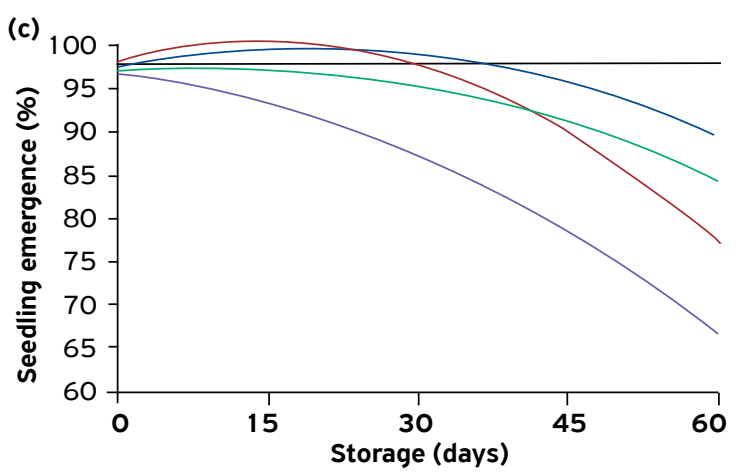

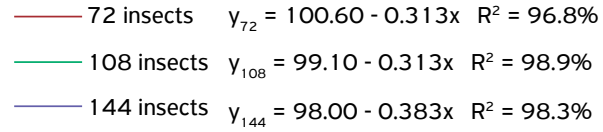

(b)

$\because \square=36 \square 72 \square 108 \square 144$
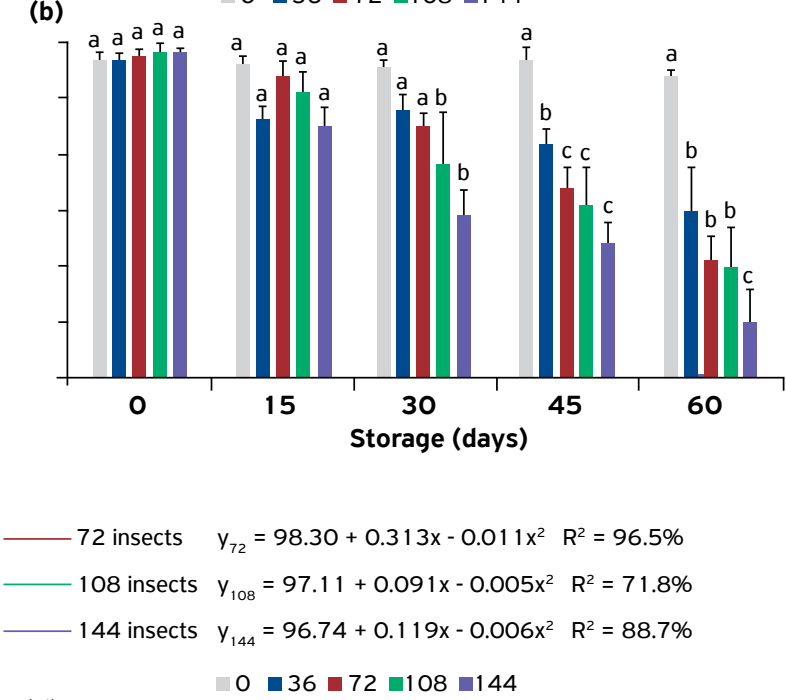

(d)

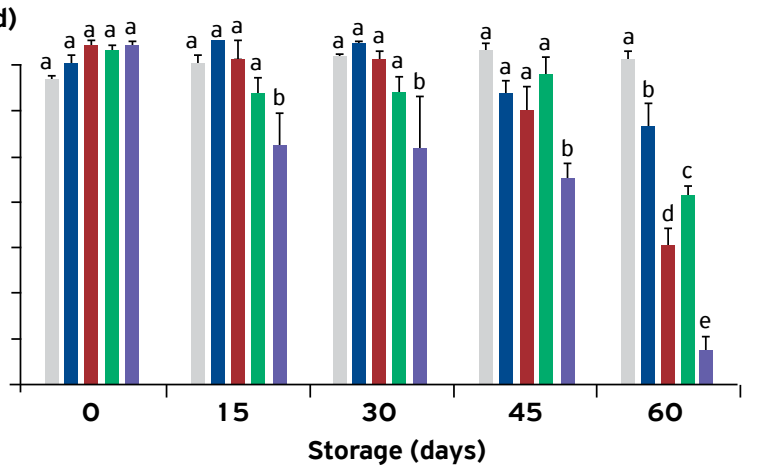

Figure 3. Percentage of germination and seedling emergence of corn seeds with different degrees of initial infestation by $S$. zeamais, evaluated during storage using regression analysis $(a, c)$ and Scott-Knott test $(b, d)$. Means followed by the same letter in each storage period are not significantly different $(p \leq 0.05)$. Bars at the top of columns indicate the media standard error.

Source: Elaborated by the authors.

The germination percentage decreased linearly during seed storage infested with S. zeamais, regardless of the number of insects used (Fig. 3a). However, the reduction in the percentage of germination of stored seeds is faster when the number of individuals used in infestation is greater. With only 60 days of storage, seeds infested with 144 individuals already had germination rates below $85 \%$, out of the standard for commercial hybrid seeds. Similarly, CANEPPELEet al. (2003) found that the germination of corn seeds showed a high inverse correlation with the number of insects and the seeds weight loss infested with S. zeamais during storage.

Even with significant differences in the number of infested seeds at 15 days of storage, a smaller extent of damage was observed in seed weight loss and, consequently, no significant differences were observed from the germination test in this period. At 30 days of storage, significant differences were observed in the percentage of germination between the different infestation levels (Fig. 3b).

For the percentage of seedling emergence, there is a quadratic tendency to reduce the quality of seeds stored with different weevil densities. The initial infestation with 36 individuals, as well as for 72 and 108, reduced seedling emergence 
mainly after 30 days of storage. For the highest level of infestation, 144 individuals, the seedling emergence percentage tends to be reduced more quickly during storage (Fig. $3 \mathrm{c}$ and $3 \mathrm{~d}$ ).

Storage pests can cause a reduction in the seeds physiological quality and affect the grains commercial classification and total loss depending on the intensity of the attack (BARBOSA et al., 2002; CANEPPELEet al., 2003).

According to CARVALHO; NAKAGAWA (2012), the damage caused by storage insects can start with injuries to the tegument, causing an increase in seed respiration and thus reducing its performance. Thus, it is important to adopt pest control measures to minimize losses by S. zeamaisin corn seeds during storage. The use of resistant varieties and botanical insecticides for managing of this insect pest (FRAZÃO et al., 2018; NWOSU, 2018) and radiographic analysis for a better evaluation of seeds (FRANÇA-SILVA et al., 2019) are innovations that can contribute to the management of pests in stored seeds.

\section{CONCLUSION}

The population increase of $S$. zeamais causes a decrease on the physical and physiological quality of stored corn seeds, but the deterioration rate does not increase in the same proportion as the weevil population growth rate.

\section{AUTHORS' CONTRIBUTIONS}

Conceptualization: Pereira, R.R.C.; Pereira, C.E. Data curation: Costa, L.O.; Marques, S.C.; Pereira, R.R.C. Formal analysis: Pereira, C.E. Funding acquisition: Pereira, C.E. Investigation: Costa, L.O.; Marques, S.C. Methodology: Pereira, R.R.C.; Pereira, C.E. Project administration: Pereira, C.E. Resources. Supervision: Pereira, C.E. Validation: Pereira, R.R.C. Writing - original draft: Costa, L.O.; Pereira, C.E. Writing - review \& editing: Pereira, R.R.C.; Pereira, C.E.

\section{AVAILABILITY OF DATA AND MATERIAL}

The datasets generated and/or analyzed during the current study are available from the corresponding author on reasonable request.

\section{FUNDING}

Fundação de Amparo à Pesquisa do Estado do Amazonas.

https://doi.org/10.13039/501100004916

\section{CONFLICTS OF INTEREST}

All authors declare that they have no conflict of interest.

\section{ETHICAL APPROVAL}

Not applicable.

\section{ACKNOWLEDGEMENTS}

Not applicable.

\section{REFERENCES}

ALAM, M.J.; AHMED, K.S.; HOSSEN, B.; HOQUE, M.; HOQUE, A.B.M.Z. Storage pests of maize and their status in Bangladesh.Journal of Bioscience and Agriculture Research, Dhaka, v.20, n.2, p.1724-1730, 2019. https://doi.org/10.18801/jbar.200219.210

BARBOSA, F.R.; YOKOYAMA, M.; PEREIRA, P.A.A.; ZIMMERMANN, F.J.P.Controle do caruncho-do-feijoeiro Zabrotes subfasciatus com óleos vegetais, munha, materiais inertes e malathion. Pesquisa Agropecuária Brasileira,Brasília, v.37, n.9, p.1213-1217, 2002. https:// doi.org/10.1590/S0100-204X2002000900002

BESKOW, P.; DECKERS, D.Capacidade brasileira de armazenagem de grãos. In: LORINI, I.; MIIKE,L.H.; SCUSSEL,V.M. (ed.).Armazenagem de grãos.Campinas:IBG, 2002. p.97-115. 
BRAZIL. Ministério da Agricultura, Pecuária e Abastecimento. Regras para análise de sementes. Brasília:MAPA,2009. 399p. Available from: https://www.gov.br/agricultura/pt-br/assuntos/insumos-agropecuarios/arquivos-publicacoes-insumos/2946_regras_analise_sementes. pdf. Access on: 09Nov.2021.

CANEPPELE, M.A.B.; CANEPPELE, C.; LÁZZARI, F.A.; LÁZZARI, S.M.N.Correlation between the infestation level of Sitophilus zeamais Motschulsky, 1855 (Coleoptera, Curculionidae) and the quality factors of stored corn, Zea mays L. (Poaceae). Revista Brasileira de Entomologia,São Paulo, v.47, n.4, p.625-630, 2003. https://doi.org/10.1590/S0085-56262003000400015

CARVALHO, N.M. de; NAKAGAWA, J. Sementes: Ciência, tecnologia e produção. Jaboticabal: Funep, 2012. 590p.

CONAB -Companhia Nacional de Abastecimento.Safra brasileira de grãos. Brasília: Conab, 2020. Available from: https://www.conab. gov.br/info-agro/safras/graos. Access on: 09 Nov. 2021.

DANHO, M.; GASPAR, C.; HAUBRUGE, E.The impact of grain quantity on the biology of Sitophilus zeamais Motschulsky (Coleoptera: Curculionidae): Oviposition, distribution of eggs, adult emergence, body weight and sex ratio.Journal of Stored Products Research,Oxford, v.38, n.3, p.259-266, 2002. https://doi.org/10.1016/S0022-474X(01)00027-3

FAO - Food and Agriculture Organization of the United Nations.FAOSTAT. Rome: FAO, 2020.Available from: http://www.fao.org/faostat/ en/\#data/QC. Access on: 09 Nov. 2021.

FERREIRA, D.F. Sisvar: A computer statistical analysis system. Ciência e Agrotecnologia, Lavras, v.35, n.6, p.1039-1042,2011. https://doi. org/10.1590/S1413-70542011000600001

FRANÇA-SILVA, F; CARVALHO, M.L.M. de; CARVALHO, G.A.; ANDRADE, D.B. de; SOUZA, V.F. de; MARQUES, E.R. Radiographic analysis to test maize seeds for the presence of Sitophilus zeamais (Coleoptera: Curculionidae). Seed Science and Technology, Zurich, v.47, n.3, p.248-259,2019. https://doi.org/10.15258/sst.2019.47.3.02

FRAZÃO, C.A.V.; SILVA, P.R.R.; ALMEIDA, W.A. de; PONTUAL, E.V.; CRUZ, G. dos S.; NAPOLEÃO, T.H.; FRANÇA, S.M. de. Resistance of maize cultivars to Sitophilus zeamais (Coleoptera: Curculionidae). Arquivos do Instituto Biológico, São Paulo, v.85, e0552017, 2018. https://doi.org/10.1590/1808-1657000552017

GALLO, D. et al. Entomologia agrícola. Piracicaba: Fealq, 2002.920p.

GUEDES, N.M.P.;GUEDES, R.N.C.;CAMPBELL, J.F.;THRONE, J.E. Contest behaviour of maize weevil larvae when competing within seeds.Animal Behaviour, New York, v.79, n.2, p.281-289, 2010. https://doi.org/10.1016/j.anbehav.2009.10.022

MARSARO JÚNIOR, A.L.; VILARINHO, A.A.; PAIVA, W.R.S.C. de; BARRETO, H.C. dos S. Resistência de híbridos de milho ao ataque de Sitophilus zeamais Motschulsky (Coleoptera: Curculionidae) em condições de armazenamento. Revista Acadêmica Ciência Animal, Curitiba, v.6, n.1, p.45-50, 2008. https://doi.org/10.7213/cienciaanimal.v6i1.10334

MUZEMU, S.; CHITAMBA, J.; MUTETWA, B.Evaluation of Eucalyptus tereticornis, Tagetes minuta and Carica papaya as stored maize grain protectants against Sitophilus zeamais (Motsch.) (Coleoptera: Curculionidae). Agriculture, Forestry and Fisheries, New York, v.2, n.5, p.196-201, 2013. https://doi.org/10.11648/j.aff.20130205.13

NUKENINE, E.N.; MONGLO, B.; AWASON, L.; NGAMO, L.S.T.; TCHUENGUEM, F.F.N.; NGASSOUM, M.B. Farmer's perception on some aspects of maize production, and infestation levels of stored maize by Sitophilus zeamais in the Ngaoundéré region of Cameroon. Cameroon Journal of Biological Biochemical Sciences, Abuja, v.12, n.1, p.18-30, 2002.

NWOSU, L.C. Maize and the maize weevil: Advances and innovations in postharvest control of the pest. Food Quality and Safety, Hangzhou, v.2, n.3, p.145-152, 2018. https://doi.org/10.1093/fqsafe/fyy011

OJO, J.A.; OMOLOYE, A.A. Development and life history of Sitophilus zeamais (Coleoptera: Curculionidae) on cereal crops. Advances in Agriculture, London, v.2016, 7836379, 2016. https://doi.org/10.1155/2016/7836379 
SILVA, A.A.L. da; FARONI, L.R.D’A.; GUEDES, R.N.C.; MARTINS, J.H.; PIMENTEL, M.A.G.Modelos analíticos do crescimento populacional de Sitophilus zeamais em trigo armazenado. Revista Brasileira de Engenharia Agrícola e Ambiental, Campina Grande, v.10, n.1, p.155-161, 2006. https://doi.org/10.1590/S1415-43662006000100023

SILVEIRA, R.D.; FARONI, L.R.D’A.; PIMENTEL, M.A.G.; ZOCOLO, G.J.Influência da temperatura do grão do milho, no momento da pulverização, e do período de armazenamento, na mortalidade de Sitophilus zeamais e Tribolium castaneum, pela mistura bifenthrin e pirimifós-metil. Revista Brasileira de Armazenamento, Viçosa, v.31, p.120-124, 2006.

SORI, W.; AYANA, A. Storage pests of maize and their status in Jimma Zone, Ethiopia. African Journal of Agricultural Research, Nairobi, v.7, n.28, p.4056-4060, 2012. https://doi.org/10.5897/AJAR11.1123

SOUSA, A.H.; FARONI, L.R.D’A.; PIMENTEL, M.A.G.; GUEDES, R.N.C. Developmental and population growth rates of phosphine resistant and susceptible populations of stored product insect pests. Journal of Stored Products Research, Oxford, v.45, n.4, p.241-246, 2009. https://doi.org/10.1016/j.jspr.2009.04.003

STEFANELLO, R.; MUNIZ, M.F.B.; NUNES, U.R.; DUTRA, C.B.; SOMAVILLA, I. Physiologicaland sanitary qualities of maize landrace seeds stored under two conditions.Ciência e Agrotecnologia, Lavras, v.39, n.4, p.339-347, 2015. https://doi.org/10.1590/S1413-70542015000400004

VIEBRANTZ, P.C.; RADUNZ, L.L.; DIONELLO, R.G. Mortality of insects and quality of maize grains in hermetic and non-hermetic storage. Revista Brasileira de Engenharia Agrícola e Ambiental, Campina Grande, v.20, n.5, p.487-492, 2016. https://doi.org/10.1590/18071929/agriambi.v20n5p487-492 